\title{
ANALISIS POTENSI DAN KUALITAS PAKAN HIJAUAN YANG TUMBUH LIAR DI LAHAN KAMPUS LIMAU MANIS UNIVERSITAS ANDALAS PADANG
}

\author{
Romadani Berutu, Puri Sardilla, Evitayani, Ifradi dan Khalil \\ Bagian Nutrisi dan Teknologi Pakan Fakultas Peternakan Universitas Andalas Padang \\ Email: khali@faterna.unand.ac.id
}

\begin{abstract}
ABSTRAK
Penelitian ini bertujuan untuk mempelajari potensi ketersediaan dan kandungan zat makanan hijauan yang tumbuh di lahan kampus Universitas Andalas di luar lahan UPT Fakultas Peternakan. Penelitian ini dilakukan dengan metode survei dan pengamatan langsung ke lapangan, Data hasil penelitian kemudian dianalisis secara statistik menggunakan analisis sidik ragam, yang terdiri atas 3 perlakuan dan 3 ulangan. Sedangkan, parameter yang diukur adalah produksi biomass, komposisi botanis, kapasitas tampung, kandungan zat makanan (Air, BK, PK, SK dan LK) dan kandungan mineral makro (Ca, Na, P, S, Mg dan K) serta mineral mikro (Cu, Zn, Fe, $\mathrm{Mn}, \mathrm{Co}$, dan Se). Hasil penelitian menunjukkan bahwa kandungan zat makanan, produksi biomass, kapasitas tampung dan kandungan mineral (makro dan mikro) menunjukkan perbedaan yang tidak nyata $(\mathrm{P}>0,05)$ pada tiga topografi. Jenis tanaman pada topografi datar dan miring didominasi oleh alang-alang (Imperata cylindrica) masing-masing 69,3\% dan 56,2\% sedangkan pada topografi gelombang didominasi oleh rumput pahit (Axonopus compressus) yang mencakup sekitar 54,4\%. Pada topografi datar kandungan protein kasarnya lebih tinggi 9,8\% BK. Pada topografi gelombang PK nya tinggi 9,4\% BK sedangkan pada topografi miring PK paling rendah 8,9\% BK. Produksi hijauan segar pada daerah yang datar merupakan produksi hijauan segar yang paling tinggi yaitu $65356,9 \mathrm{~kg} / \mathrm{ha} / \mathrm{th}$. Sedangkan produksi hijauan kering tertinggi adalah pada topografi miring $12180,13 \mathrm{~kg} / \mathrm{ha} / \mathrm{th}$. Kapasitas tampung per hektar (ST/ha) pada setiap topografi berkisar antara 1,68 (ST/ha) sampai 2,22 (ST/ha). Kapasitas tampung tertinggi adalah pada lahan miring 2,22 (ST/ ha) dan disusul oleh lahan yang bertopografi datar 2,13 (ST/ha). Sedangkan pada lahan yang bergelombang memiliki kapasitas tampung terendah yaitu 1,68 (ST/ha). Kandungan mineral pada setiap topografi juga menunjukkan perbedaan yang tidak nyata. Mineral makro tertinggi terdapat pada lahan yang bertopografi datar P 1,03 g/kg BK, Mg 1,53 g/kg BK, K 13,03 g/kg BK, Na 15,84 g/kg BK, S o,17 g/kg BK kecuali Ca $8,13 \mathrm{~g} / \mathrm{kg}$ BK. Sedangkan kandungan mineral mikro tertinggi berada pada topografi miring Zn 36,16 mg/ $\mathrm{kg} \mathrm{BK}, \mathrm{Fe} 804,00 \mathrm{mg} / \mathrm{kg} \mathrm{BK}, \mathrm{Mn} 171,52 \mathrm{mg} / \mathrm{kg}$ BK kecuali Cu 16,03 mg/kg BK. Dari hasil penelitian dapat disimpulkan bahwa hijauan yang tumbuh di lahan kampus Universitas Andalas Limau Manis di luar lahan UPT Peternakan berpotensi sebagai pakan ternak ruminan. Rumput yang berasal dari topografi datar relatif lebih baik dari kandungan zat makanan maupun mineralnya.
\end{abstract}

\section{Kata kunci : Produksi hijauan, kapasistas tampung, komposisi zat makanan}

\section{PENDAHULUAN}

Fakultas Peternakan Universitas Andalas sebagai salahsatu lembaga pendidikan tinggi di bidang peternakan memiliki tanggungjawab untuk membantu pemerintah dalam upaya pemenuhan kebutuhan daging masyarakat serta mengurangi ketergantungan terhadap sapi impor. Fakultas Peternakan memiliki lahan dan sarana untuk memelihara ternak sapi dalam skala komersial berupa Unit Pelaksana Teknis (UPT) Peternakan.

UPT Peternakan yang berlokasi di kampus Limau Manis didesain dan diperuntukkan untuk memelihara beragam jenis ternak untuk melayani kebutuhan pendidikan, penelitian dan pengabdian masyarakat oleh mahasiswa maupun dosen. Sebagian besar lahan UPT Peternakan yang mencakup sekitar 28 hektar dialokasikan untuk memelihara ternak ruminan berupa kandang dan lahan padang rumput. Jika fasilitas ini dimanfaatkan secara optimal, maka UPT Peternakan dapat memelihara sekitar 100 ekor ternak sapi. Selain digunakan untuk membantu kegiatan pendidikan (praktikum) dan penelitian mahasiswa serta dosen, usaha pemeliharaan sapi ini juga dapat diharapkan menjadi sumber pendapatan untuk membantu pendanaan Fakultas.

Kendala utama pemeliharaan ternak sapi yang dihadapi UPT adalah keterbatasan ketersediaan hijauan sebagai pakan utama ternak ruminan. Sampai saat ini, sumber hijauan berasal dari lahan padang rumput milik UPT. Berdasarkan hasil penelitian Infitria (2012) lahan padang rumput UPT yang mencakup sekitar 3 ha hanya mampu menyediakan pakan hijauan untuk 13 unit ternak. Meskipun lahan 
padang rumput ditanami rumput unggul seperti rumput gajah (Pennisetum purpureum) dan rumput bede (Brachiaria decumbens), akan tetapi produksi hijauannya masih rendah.

Disampimg luas area padang rumput yang terbatas (sekitar 3 ha), menurut Infitria (2012) keterbatasan ketersediaan hijauan disebabkan oleh produktivitas lahan padang rumput yang rendah. Hal ini disebabkan oleh faktor pengelolaan lahan yang kurang optimal. Disamping itu, pertumbuhan hijauan dipengaruhi oleh faktor musim.

Pada musim hujan produksi hijauan cenderung meningkat sedangkan pada musim kemarau rumput tidak dapat tumbuh dengan baik karena ketiadaan sarana irigasi. Selanjutnya, kualitas hijauan dari padang rumput UPT juga rendah, karena tingginya kandungan serat kasar $(42,3 \%)$ dan rendah protein (10,6\%) (Infitria, 2012). Disamping memperbaiki manajemen padang rumput untuk mengatasi keterbatasan hijauan dan upaya meningkatkan jumlah ternak sapi yang dipelihara di UPT, sebaiknya UPT Peternakan memanfaatkan sumber hijauan yang tersedia di luar UPT di lingkungan kampus.

Lahan kampus Universitas Andalas Limau Manis yang mencakup lahan sekitar 479 ha merupakan sumber hijauan yang berpotensi untuk dimanfaatkan sebagai sumber hijauan. Sebagian besar lahan di kampus Limau Manis ini ditumbuhi oleh hijauan yang tumbuh secara alami. Hijauan yang ada di lahan tersebut dapat dimanfaatkan sebagai sumber hijauan ternak ruminan.

Penelitian ini bertujuan untuk mengetahui potensi dan kualitas hijauan yang ada di Universitas Andalas di luar lahan UPT Fakultas Peternakan dari aspek produksi biomass hijauan dan kapasitas tampung, komposis botanis kandungan zat makanan dan mineral.

\section{MATERI DAN METODE}

Penelitian ini dilakukan dengan metode survei dan pengamatan langsung ke lapangan, sampel di ambil dengan metode random sampling dengan cara pengambilan sampel yang memberikan kesempatan yang sama untuk diambil kepada elemen populasi (Sugiarto et al, 2003). Lahan yang dipilih ada enam lahan antara lain: Arboretum Andaleh, Kebun Tanaman Obat, Kebun Percobaan Pertanian, lahan UPT Fakultas Peternakan yang belum digarap, lahan tidur belakang Fakultas Teknik dan lahan sekitar Perumahan Dosen (Tabel 1) .

Lahan terpilih mewakili 3 bagian berdasarkan topografi, yaitu yaitu lahan datar, miring dan gelombang. Pada Tabel 2 disajikan titik pengambilan sampel pada lahan terpilih. Pada setiap topografi ditetapkan 5 titik sampling, dengan cara membagi lahan secara proporsional. Pada setiap titik sampling ditempatkan plate meter secara acak untuk mendapatkan sampel hijauan.

Hijauan yang berada di dalam plate meter dipotong pada bagian atas tanah kira-kira $2 \mathrm{~cm}$. Hijauan yang diambil dimasukkan ke dalam kantong plastik kemudian diberi tanda dengan memakai kertas label atau spidol untuk memastikan titik sampling dan diikat menggunakan tali agar kondisi berat segar hijauannya tidak berkurang. Hijauan yang didapat dibawa ke laboratorium untuk ditimbang berat segarnya. Hasil penimbangan berat segar dicatat pada formulir pengambilan sampel.

Hijauan yang sudah ditimbang berat segarnya dipisahkan menurut jenis hijauannya dan setiap jenis hijauan ditimbang. Jenis hijauan dan hasil timbangan hijauan ditulis ke dalam formulir komposisi botanis. Hijauan yang sudah ditimbang kemudian digabungkan kembali untuk dijadikan sampel analisa.

Hijauan kemudian dicacah dengan dan diambil sampel sekitar $100 \mathrm{~g}$ untuk dikeringkan di dalam oven $60^{\circ} \mathrm{C}$. Setelah didinginkan dan ditimbang berat kering udaranya, sampel kemudian digiling menjadi tepung siap untuk dianalisa.

Parameter yang diukur antara lain komposisi botanis, produksi biomass, kapasitas tamping, kandungan bahan kering dan zat makanan (PK, SK, $\mathrm{LK}$ ), kandunngan mineral makro (Ca, $\mathrm{P}, \mathrm{K}, \mathrm{Mg}, \mathrm{S}$, $\mathrm{Na})$ dan mikro ( $\mathrm{Cu}, \mathrm{Zn}, \mathrm{Mn}, \mathrm{Co}, \mathrm{Fe}, \mathrm{Se})$.

Data hasil penelitian kemudian didianalisis secara statistik menggunakan analisis sidik ragam dengan rancangan acak lengkap, yang terdir atas 3 perlakuan dan 3 ulangan. Sebagai perlakuan adalah 3 topografi lahan yang berbeda, yaitu datar, miring dan gelombang. Setiap topografi dipilih 3 lokasi lahan sebagai ulangan.

\section{HASIL DAN PEMBAHASAN}

\section{A. Komposisi Botanis}

Pada Tabel 3 disajikan data hasil analisa komposisi botanis hijauan yang berasal dari tiga topografi berbeda di enam lahan terpilih : Arboretum Andaleh, Kebun Tanaman Obat, belakang Fakultas Teknik, UPT Fakultas Peternakan yang belum digarap, Kebun Percobaan Pertanian serta sekitar Perumahan Dosen. Jenis tanaman pada setiap topografi lahan terlihat berbeda. Pada topografi datar jumlah hijauan lebih beragam yaitu enam jenis tanaman sedangkan pada lahan miring lima jenis tanaman dan empat jenis tanaman pada topografi gelombang. Jenis tanaman pada topografi datar dan miring didominasi oleh Alang-alang (Imperata cylindrical) masing-masing $69,3 \%$ dan $56,2 \%$ sedangkan pada topografi gelombang 
Tabel 1. Deskripsi Lahan Sumber Hijauan di Universitas Andalas

\begin{tabular}{|c|c|c|}
\hline Lokasi & Deskripsi Lahan & Topografi \\
\hline $\begin{array}{l}\text { Arboretum } \\
\text { Andaleh }\end{array}$ & $\begin{array}{l}\text { Lahan ini merupakan bagian dari Kebun Raya Universitas Andalas. Lahan dikelola oleh Fakultas Matemati- } \\
\text { ka dan Ilmu Pengetahuan Alam. Luas lahan sekitar } 25 \text { ha. Arboretum Andaleh ini ditanami tumbuhan obat } \\
\text { dan pepohonan. Contoh tanaman : Jeruk nipis (Citrus aurantifolia), kumis kucing (Orthosipon aristatus), } \\
\text { jambu biji (Psidium guajava). Penanaman tumbuhan pada Arboretum Andaleh ini kira-kira satu sampai } \\
\text { dua meter. Pada setiap jarak tanaman ditumbuhi oleh rumput. Rumput pada lahan ini dapat dimanfaat- } \\
\text { kan sebagai pakan ternak.Topografi lahan dominan adalah gelombang. Lahan ini berada di sebelah barat } \\
\text { Universitas Andalas. }\end{array}$ & Gelombang \\
\hline $\begin{array}{l}\text { Kebun Tanaman } \\
\text { Obat }\end{array}$ & $\begin{array}{l}\text { Kebun tanaman obat ini merupakan lahan bagian dari kebun raya Fakultas Farmasi. Lahan ini dikelola oleh } \\
\text { Fakultas. Farmasi Universitas Andalas. Tanaman yang dibudidayakan adalah tanaman obat. Contoh tana- } \\
\text { man yang berada pada lokasi ini antara lain : sereh wangi (Cymbopogon nardus), jahe (Zingiber officinale), } \\
\text { Sambiloto (Andrographis paniculata). Sebagain lahan yang berada pada lokasi ini ditumbuhi rumput. } \\
\text { Rumput yang berada disekitar tanaman tumbuh secara alami yang tidak termanfaatkan oleh jurusan } \\
\text { Farmasi. Topografi lahan adalah gelombang dan datar. Lokasi lahan berada di sebelah selatan UPT Fakultas } \\
\text { Peternakan Universitas Andalas. }\end{array}$ & $\begin{array}{c}\text { Datar } \\
\text { Gelombang }\end{array}$ \\
\hline $\begin{array}{l}\text { UPT Fakultas } \\
\text { Peternakan }\end{array}$ & $\begin{array}{l}\text { Lahan ini merupakan bagian dari lahan UPT Fakultas Peternakan yang belum digarap oleh Fakultas Pe- } \\
\text { ternakan. Lahan yang sekitar } 8 \text { ha ini ditumbuhi oleh rumput liar secara alami. Topografi lahan ini adalah } \\
\text { datar dan miring. Lokasi ini berada di sebelah selatan UPT Fakultas Peternakan. }\end{array}$ & $\begin{array}{l}\text { Datar } \\
\text { Miring }\end{array}$ \\
\hline Fakultas Teknik & $\begin{array}{l}\text { Fakultas Teknik Universitas Andalas yang berada di sebelah timur Universitas Andalas memiliki lahan yang } \\
\text { cukup luas. Sebagian lahan dari Fakultas ini merupakan lahan tidur yang ditumbuhi oleh rumput. Topo- } \\
\text { grafi lahan adalah datar. }\end{array}$ & Datar \\
\hline $\begin{array}{l}\text { Sekitar Perumahan } \\
\text { Dosen }\end{array}$ & $\begin{array}{l}\text { Lahan tidur yang berada di sekitar perumahan dosen ini sebagian besar ditumbuhi oleh rumput yang tum- } \\
\text { buh secara alami. Topografi lahan ini adalah miring. Lahan ini berlokasi di belakang Fakultas Kedokteran } \\
\text { jurusan Psikologi Universitas Andalas atau sebelah utara Universitas Andalas. }\end{array}$ & Miring \\
\hline $\begin{array}{l}\text { Kebun Percobaan } \\
\text { Pertanian }\end{array}$ & $\begin{array}{l}\text { Kebun percobaan pertanian Fakultas Pertanian yang dikelola oleh Fakultas Pertanian memiliki luas lahan } \\
\text { sekitar } 15 \text { ha berada di sebelah utara barat Universitas Andalas yang digunakan untuk kegiatan pratikum, } \\
\text { penelitian dan produksi. Sebagaian besar lahan ditumbuhi hijauan yang dapat dijadikan sumber pakan } \\
\text { ternak ruminan Fakultas Peternakan. }\end{array}$ & $\begin{array}{l}\text { Miring } \\
\text { Gelombang }\end{array}$ \\
\hline
\end{tabular}

Tabel 2. Titik Pengambilan Sampel pada Lahan Terpilih

\begin{tabular}{ll}
\hline \multicolumn{1}{c}{ Topografi } & \multicolumn{2}{l}{ Lahan } \\
\hline 1. Datar & 1. Kebun Tanaman Obat \\
& 2. Belakang Fakultas Teknik \\
2. Miring & 3. Lahan UPT Fakultas Peternakan \\
& 1. KebunPercobaan Pertanian \\
& 2. Lahan UPT Fakultas Peternakan \\
4. Gelombang & 3. Perumahan Dosen \\
& 1. Arboretum Andaleh \\
& 2. Kebun Tanaman Obat \\
& 3. Kebun Percobaan Pertanian \\
\hline
\end{tabular}

didominasi oleh rumput pahit (Axonopus compressus) yang mencakup sekitar $54,4 \%$.

Pada topografi datar didominasi oleh alangalang 69,3\% hal ini karena alang-alang merupakan rumput yang menyukai lahan terbuka, tempat-tempat dengan kesuburan tanah yang rendah dan asam serta tidak dapat tumbuh bila mendapat naungan penuh. Hairiah et al (2000) menyatakan bahwa alang-alang merupakan jenis tanaman yang suka tumbuh pada lahan yang terbuka untuk mendapat pencahayaan.

Pada topografi miring jenis tanaman didominasi oleh Imperata cylindrical $56,24 \%$ disusul oleh Axonopus compressus 24,31\% dan Cyperus rotundus $14,61 \%$. Banyaknya tumbuhan alang-alang ini pada topografi miring dikarenakan alang-alang dapat tumbuh pada berbagai keadaan lingkungan dan kesuburan tanah yang rendah.

Pada topografi miring kesuburan tanahnya rendah karena sering terjadi erosi tanah sehingga kandungan unsur hara tanah terbawa ketika hujan. Notohadiprawiro (1991) menyatakan bahwa ekspor impor bahan tanah dan air merupakan ekspor dan impor zat hara. Ekspor impor secara berangsur dapat memiskinkan tanah atasan dan secara berangsur mengayakan tanah bawahan.

Akan tetapi berbeda pada topografi gelombang yang didominasi oleh Axonopus compressus (Rumput pahit). Hal ini dikarenakan rumput pahit merupakan jenis rumput yang tumbuh baik pada naungan. Suyitman et al (2003) menyatakan bahwa rumput pahit dapat hidup di daerah tropik yang humid dan sub tropik. Tumbuh paling baik di tanah berpasir, liat, mineral dan bahan organik basah serta dapat tahan genangan air sementara. Tumbuh baik pada naungan yang tidak menyeluruh dan pertumbuhannya pada musim kemarau sangat lambat.

Pada topografi gelombang tidak ada rumput teki. Rumput teki ada pada topografi miring $14,61 \%$ dan topografi datar $6,51 \%$. Hal ini dikarenakan rumput teki (Cyperus rotondus) adalah jenis rumput yang tumbuh pada lahan yang kering dan tegalan. Rukmana (1999) menyatakan bahwa golongan teki meliputi semua jenis tumbuhan yang termasuk ke dalam family Cyperaciae. Golongan teki terdiri dari 
Tabel 3. Komposisi Botanis (\%) hijauan di Topografi Datar, Miring dan Gelombang

\begin{tabular}{|c|c|c|c|c|}
\hline No & Jenis Tanaman & Datar & Miring & Gelombang \\
\hline 1 & $\begin{array}{l}\text { Alang-alang } \\
\text { (Imperata cylindrica) }\end{array}$ & 69,27 & 56,24 & 29,84 \\
\hline 2 & $\begin{array}{l}\text { Rumput Pahit } \\
\text { (Axonopus compressus) }\end{array}$ & 16,64 & 24,31 & 54,43 \\
\hline 3 & $\begin{array}{l}\text { Rumput Teki } \\
\text { (Cyperus rotundus) }\end{array}$ & 6,51 & 14,61 & - \\
\hline 4 & $\begin{array}{l}\text { Putri Malu } \\
\text { (Mimosa pudica) }\end{array}$ & 3,64 & 2,20 & 14,14 \\
\hline 5 & $\begin{array}{l}\text { Rumput Udang } \\
\text { (Ascrescents cyrtococcus) }\end{array}$ & - & 2,65 & 1,59 \\
\hline 6 & $\begin{array}{l}\text { Rumput Bintang } \\
\text { (Cynodon } \\
\text { dactylon) }\end{array}$ & 3,90 & - & - \\
\hline \multirow[t]{2}{*}{7} & Rumput Akar Wangi & 0,04 & - & - \\
\hline & Jumlah & 100.0 & 100.0 & 100.0 \\
\hline
\end{tabular}

90 genera 400 spesies adalah jenis tanaman yang lebih menyukai air, kecuali Cyperus rotundus. Akan tetapi pada topografi gelombang jumlah tumbuhan legume (Mimosa pudica) 14,14 lebih banyak daripada topografi datar maupun miring 3,64\% dan 2,20\%. Lain halnya dengan rumput bintang (Cynodon dactylon), rumput ini hanya terdapat pada topografi datar. Hal ini dikarenakan pada topografi datar kondisi drainase tanahnya masih baik dan tidak ada naungan, sehingga rumput bintang dapat tumbuh. Rumput bintang ini merupakan rumput yang tahan kekeringan karena adanya rhizom akan tetapi hasil hijauan menjadi sedikit terutama pada tanah dengan kesuburan yang marjinal. Rumput akan mati apabila ternaungi atau terlindungi (Suyitman et al, 2003).

\section{B. Kandungan Zat Makanan}

Pada Tabel 4 disajikan hasil analisa kandungan zat makanan hijauan pada tiga topografi lahan. Zat makanan yang dianalisa air, berat kering (BK), abu, protein kasar (PK), lemak kasar (LK) dan serat kasar (SK). Pada tiga topografi kandungan airnya cukup tinggi sekitar 80\% sedangkan kandungan berat keringnya rendah sekitar $20 \%$.

Kandungan protein bahan pakan merupakan salah satu ukuran kualitas suatu bahan pakan. Protein kasar merupakan zat makanan yang penting bagi kehidupan. Istilah protein kasar digunakan untuk menggolongkan semua ikatan nitrogen dalam bahan makanan. Pada daerah tropika kandungan protein dari rumput kirakira 7\% (Crowder and Chheda, 1982).

Hasil analisa statistik menyatakan bahwa kandungan zat makanannya menunjukkan perbedaan yang tidak nyata pada tiga topografi, namun secara angka terlihat berbeda pada masing-masing topografi. Pada topografi datar protein kasar nya lebih tinggi 9,8\% BK dan disusul 9,4\% BK topografi gelombang. Ini dikarenakan pada topografi datar kondisi fisik tanahnya masih baik dan kandungan unsur hara pada tanah tercukupi untuk tanaman.

Pada topografi gelombang PK tinggi disebabkan karena jumlah Mimosa pudica nya tinggi $14,14 \%$ terlihat pada Tabel 3. Nitrogen merupakan salah satu unsur mineral yang essensial bagi tanaman dan berperan dalam pertumbuhan vegetatif meliputi pertumbuhan akar, batang dan daun. Unsur ini yang diserap tanaman dalam bentuk nitrat $\left(\mathrm{NO}_{3}\right)$ dan ammonium $\left(\mathrm{NH}_{4}+\right)$. Ion-ion ammonium dan beberapa karbonat mengalami sintesis dalam daun diubah menjadi asam amino terjadi pada hijau daun dan apabila unsur nitrogen tersedia dengan tepat dapat menghasilkan protein yang tinggi (Sarief, 1989).

Tabel 4. Hasil Analisa Kandungan Zat Makanan Hijauan yang Berasal dari Lahan pada Topografi Berbeda

\begin{tabular}{|c|c|c|c|c|c|c|}
\hline \multirow{3}{*}{ Topografi } & \multirow{2}{*}{ Air } & \multirow{2}{*}{ BK, } & \multicolumn{4}{|c|}{ Zat Makanan, } \\
\hline & & & Abu & PK & LK & SK \\
\hline & \multicolumn{2}{|c|}{...\%BS ... } & \multicolumn{4}{|c|}{...\%BK ... } \\
\hline Datar & 82,4 & 17,6 & 9,3 & 9,8 & 4,1 & 29,2 \\
\hline Miring & 78,6 & 21,4 & 11,5 & 8,9 & 3,2 & 29,4 \\
\hline Gelombang & 83,2 & 16,8 & 9,4 & 9,4 & 4,1 & 33,8 \\
\hline
\end{tabular}

Pada topografi miring mengandung protein kasar (PK) yang paling rendah 8,9\% BK. Rendahnya protein kasar pada topografi ini karena kondisi fisik tanah yang sudah terkena erosi sehingga kandungan unsur hara pada tanah rendah. Unsur hara yang ada di tanah pada topografi miring ini terbawa oleh air hujan.

Proses erosi dapat menyebabkan merosotnya produktivitas dan daya dukung tanah untuk produksi pertanian serta menurunnya kualitas lingkungan hidup (Sarief, 1986). Soepardi (1983) menambahkan bahwa akibat terjadinya erosi, selain partikel-partikel tanah yang dihanyutkan adalah unsur-unsur haranya. Rendahnya kandungan $\mathrm{N}$ akan mengakibatkan turunnya kadar protein serta perbandingan protoplasma dengan dinding sel daun dengan ukuran sel yang kecil dengan demikian daun akan menjadi keras penuh dengan serat-serat (Sarief, 1986).

Kandungan zat makanan yang tidak kalah pentingnya adalah kandungan serat kasar. Rata-rata kandungan serat kasar pada setiap topografi adalah $29-33 \%$ BK. Kandungan serat kasar pada topografi gelombang lebih tinggi 33,8\% BK dibandingkan dengan lahan bertopografi datar 29,2\% BK dan miring 29,4\% BK.

Tingginya SK pada topografi gelombang dikarenakan curah hujan di kota padang tinggi yaitu rata-rata $>600 \mathrm{~mm} / \mathrm{hg}$ setiap bulannya (BMKG, 2013). Curah hujan yang tinggi menyebabkan ukuran sel daun kecil sehingga daun akan keras dan penuh dengan serat-serat.

Hal ini sesuai dengan pendapat Ammar et al., 
(1991) menyatakan bahwa curah hujan yang tinggi menyebabkan sedikit intensitas cahaya yang akan membuat dinding sel menjadi banyak dan inti sel nya sedikit.

Kandungan abu pada setiap topografi berbedabeda. Besarnya kandungan mineral tanaman terlihat dari besarnya nilai kadar abu dari proses pengabuan. Abu tertinggi pada topografi miring $11,5 \%$ hal ini dikarenakan pada topografi miring terlihat bahwa jumlah bahan keringnya juga tinggi 21,4\%. Bahan kering dari hijauan ini berpengaruh terhadap kandungan abunya karena bahan kering mengandung abu. Sesuai dengan pendapat Fathul dan Wajizah (2010) menyatakan bahwa bahan organik merupakan bagian dari bahan kering, sehingga apabila bahan kering meningkat akan meningkatkan bahan organik begitu juga sebaliknya.

\section{Kandungan Mineral}

Pada Tabel 5 disajikan hasil analisa kandungan mineral makro dan mikro hijauan pada tiga topografi lahan berbeda yaitu datar, mring dan gelombang. Mineral makro yang dianalisa adalah kalsium $(\mathrm{Ca})$, fosfor (P), magnesium (Mg), kalium (K), natrium (Na), dan sulfur (S) sedangkan mineral mikro yang dianalisa adalah tembaga $(\mathrm{Cu})$, seng $(\mathrm{Zn})$, besi $(\mathrm{Fe})$, mangan (Mn), kobalt (Co) dan selenium (Se). Hasil analisa statistik menunjukkan bahwa kandungan mineral makro dan mikro pada ketiga topografi lahan memberikan pengaruh yang berbeda tidak nyata $(\mathrm{P}>0,05)$.

Unsur mineral makro berperan penting dalam aktivitas fisiologis dan metabolisme tubuh (Mc Dowell 1985) sedangkan unsur mineral mikro berfungsi untuk aktivitas sistem enzim dan hormon dalam tubuh. Menurut Marschner (1995) kandungan Ca dalam tanaman antara $0,1->5,0 \%$ dari berat kering tergantung kondisi pertumbuhan, jenis tumbuhan dan bagian tumbuhan sedangkan untuk tumbuh optimal tanaman memerlukan $0,3-0,5 \% \mathrm{P}$ dari berat kering. Pada umumnya S yang dibutuhkan untuk pertumbuhan optimal tanaman bervariasi antara 0,1 sampai $0,5 \%$ dari bobot kering tanaman (Marschner, 1995).

McDonald et al., (2002) menambahkan bahwa konsentrasi kalium pada hijauan dinyatakan rendah apabila konsentrasinya lebih kecil dari $12 \mathrm{~g} / \mathrm{kg}$ bahan kering. Kandungan mineral Na pada rumput penggembalaan tertutup dan intensif adalah 1,9 dan $1,7 \mathrm{~g} / \mathrm{kg}$ (McDonald et al., 1995).

Menurut Davis dan Mertz (1987) kadar mineral $\mathrm{Cu}$ di dalam bahan kering hijauan sebesar 0,6 mg/ $\mathrm{kg}$ adalah cukup bagi keperluan hewan ternak dan kebutuhan tembaga $(\mathrm{Cu})$ sehari-hari ternyata adalah $50 \mathrm{mg} / \mathrm{kg}$ ransum untuk sapi sedangkan kandungan
Tabel 5. Hasil Analisa Kandungan Mineral (makro dan mikro) di Lahan Kampus Limau Manis Universitas Andalas

\begin{tabular}{lrrrr}
\hline \multirow{2}{*}{ Parameter } & \multicolumn{4}{c}{ Topografi } \\
\cline { 2 - 4 } Mineral makro (g/kg BK) & Datar & Miring & Gelombang & \\
Ca & & & & \\
P & 6,68 & 8,13 & 3,48 & 6,10 \\
Mg & 1,03 & 1,01 & 0,44 & 0,83 \\
K & 1,53 & 1,62 & 0,86 & 1,34 \\
Na & 13,03 & 10,92 & 9,31 & 11,09 \\
S & 15,84 & 12,79 & 10,52 & 13,05 \\
Mineral mikro (mg/kg BK) & 0,17 & 0,15 & 0,17 & 0,16 \\
Cu & & & & \\
Zn & 16,03 & 14,50 & 8,98 & 13,17 \\
Fe & 34,49 & 36,16 & 23,13 & 31,26 \\
Mn & 605,61 & 804,00 & 431,88 & 613,83 \\
Co & 123,04 & 171,52 & 135,17 & 143,24 \\
Se & $<0,005$ & $<0,005$ & $<0,005$ & \\
\hline
\end{tabular}

seng (Zn) dalam hijauan rumput adalah 30-50 mg/ $\mathrm{kg}$ BK. McDonald et al. (2002) menyatakan bahwa konsentrasi besi $(\mathrm{Fe})$ pada hijauan berada pada kisaran tinggi apabila konsentrasinya lebih dari $200 \mathrm{mg}$ $\mathrm{Fe} / \mathrm{kg}$ bahan kering sementara batas kandungan normal mineral Mn dalam rumput adalah 60-800 ppm. Tillman dkk., (1989) mengatakan bahwa kebanyakan bahan makanan Co dan pasture yang normal mengandung 0,1-0,25 mg/kg bahan kering. Hijauan yang mengandung Co kurang dari $0,1 \mathrm{mg} / \mathrm{kg}$ bahan kering dikatakan rendah dan perlu suplementasi. Dilaga (1992) menjelaskan bahwa secara alamiah ketersediaan Se di dalam tanah sangat sedikit.

Pada Tabel 5 terlihat bahwa kandungan $\mathrm{K}$ dan $\mathrm{Na}$ lebih tinggi terdapat di topografi datar yaitu masingmasing sebesar 13,03 g/kg BK dan 15,84 g/kg BK. Kandungan mineral $\mathrm{K}$ yang tinggi pada topografi datar disebabkan oleh perbedaan spesies tanaman dan kandungan protein tanaman yang tumbuh pada lokasi tersebut. Menurut Foth (1984) bahwa spesies tanaman dan kandungan protein sangat berpengaruh terhadap konsentrasi unsur mineral yang terkandung di dalamnya. Sementara kandungan mineral Na yang tinggi pada topografi datar disebabkan oleh kondisi alam tempat tumbuhnya hijauan memiliki kandungan garam yang tinggi.

Menurut Tangdilintin (2002) bahwa kandungan mineral dalam tanaman pakan ternak antara lain tergantung pada tipe tanah tempat tumbuhnya tanaman. Sementara kandungan mineral Ca lebih tinggi terdapat pada topografi miring yaitu sebesar $8,13 \mathrm{~g} / \mathrm{kg}$ BK. Hal ini disebabkan karena pada topografi miring terdapat sejenis leguminosa yang tumbuh. Menurut Foth (1984) bahwa pada tanaman leguminosa kandungan $\mathrm{N}$ dan $\mathrm{K}$ nya lebih rendah daripada rumput-rumputan, sebaliknya unsur Ca nya lebih tinggi. 
Tabel 6. Produksi Biomas (Segar dan Kering) dan Kapasitas Tampung

\begin{tabular}{lrrrr}
\hline \multirow{2}{*}{ Parameter } & \multicolumn{1}{c}{ Topografi } & \multirow{2}{*}{ Rataan } \\
\cline { 2 - 4 } & \multicolumn{1}{c}{ Datar } & \multicolumn{1}{c}{ Miring } & Gelombang & 58517,61 \\
Produksi Hijauan Segar (Kg/ha/th) & 65356,90 & 56854,83 & 53341,10 & 160,32 \\
Produksi Hijauan Segar harian (Kg/ha/hr) & 179,06 & 155,77 & 146,14 & 11015,37 \\
Produksi Hijauan Kering (Kg/ha/th) & 11641,06 & 12180,13 & 9224,93 & 30,18 \\
Produksi Hijauan Kering (Kg/ha/hari) & 31,89 & 33,37 & 25,27 & 2,01 \\
Kapasitas Tampung (ST/ha) & 2,13 & 2,22 & 1,68 & \\
\hline
\end{tabular}

Kandungan mineral Zn, Fe dan Mn pada Tabel 5 terlihat lebih tinggi terdapat pada topografi miring. Hal ini dikarenakan hijauan yang tumbuh pada topografi miring memiliki perakaran yang dalam sehingga bisa menyerap mineral pada lapisan tanah paling dalam. Selain itu rumput yang tumbuh pada topografi miring memiliki fungsi sebagai penutup tanah sehingga mengurangi pencucian unsur hara yang terdapat di lapisan tanah paling atas.

\section{Produksi Biomass dan Kapasitas Tampung}

Pada Tabel 6 disajikan hasil produksi biomas dalam bentuk segar dan kering.. Hasil analisa statistik menyatakan bahwa produksi biomass dan kapasitas tampung menunjukkan perbedaan yang tidak nyata pada tiga topografi, namun secara angka produksi biomass dan kapasitas tampung terlihat berbeda.

Produksi hijauan segar pada daerah yang datar merupakan produksi hijauan segar yang paling tinggi yaitu $65356,9 \mathrm{~kg} / \mathrm{ha} / \mathrm{th}$ ini disebabkan karena pada lahan yang datar hijauan yang di dapat lebih banyak jumlah. Disamping itu, curah hujan pada bulan Desember 2013 cukup tinggi > $600 \mathrm{~mm} / \mathrm{hg}$ per bulannya.

Tingginya curah hujan ini menyebabkan produksi hijauan tinggi karena kebutuhan air tanaman tercukupi. Selanjutnya disusul oleh topografi miring $56857,83 \mathrm{~kg} / \mathrm{ha} / \mathrm{th}$ dan gelombang $53341,1 \mathrm{~kg} / \mathrm{ha} / \mathrm{th}$.

Produksi hijauan kering tertinggi adalah pada topografi miring $12180,13 \mathrm{~kg} / \mathrm{ha} / \mathrm{th}$. Hal ini dipengaruhi oleh kandungan bahan kering yang tinggi 21,4\% terlihat pada Tabel 4 disebabkan produksi hijauan segar pada topografi ini juga tinggi 56854,83 $\mathrm{kg} / \mathrm{ha} /$ th. Sitompul clan Guritno (1995) dan Erwanto (1984) juga menyatakan bahwa peningkatan produksi hijauan segar akan diikuti dengan peningkatan bahan keringnya.

Kapasitas tampung merupakan cerminan dari produktivitas dari suatu padang penggembalaan. Kapasitas tampung perhektar (ST/ha) pada setiap topografi berkisar antara 1,68 (ST/ha) sampai 2,22 (ST/ha). Kapasitas tampung tertinggi adalah pada lahan miring 2,22 (ST/ha) dan disusul oleh lahan yang bertopografi datar 2,13 ST/ha. Sedangkan pada lahan yang bergelombang memiliki kapasitas tampung terendah yaitu 1,68 (ST/ha). Hal ini dikarenakan produksi hijauan pada topografi miring maupun datar tinggi 56854,83 dan $65356,9 \mathrm{~kg} / \mathrm{ha} / \mathrm{th}$.

Sedangkan kapasitas tampung terendah ada pada topografi gelombang ini dikarenakan produksi hijauan segarnya rendah $53341,1 \mathrm{~kg} / \mathrm{ha} / \mathrm{th}$. Kapasitas tampung berhubungan erat dengan produktivitas hijauan pakan pada suatu areal penggembalaan ternak. Makin tinggi produktivitas hijauan pada suatu areal padang penggembalaan, makin tinggi pula kapasitas tampung ternak yang ditunjukkan dengan banyaknya ternak yang dapat digembalakan (Junaidi.M dan Diana Sawen, 2010).

Dapat dikatakan bahwa, kapasitas tampung pada topografi datar maupun miring cukup baik. Rata-rata kapasitas tampung pada kedua topografinya adalah dua unit ternak per hektarnya. Hal ini didasarkan atas pendapat Mc Ilroy (1977), bahwa kapasitas tampung daerah tropik umumnya sebesar 2-7 unit ternak per hektar.

\section{SIMPULAN}

Berdasarkan hasil penelitian dapat disimpulkan bahwa hijauan yang tumbuh di lahan Universitas Andalas di luar lahan UPT Fakultas Peternakan berpotensi untuk dimanfaatkan sebagai pakan ternak ruminan. Kandungan zat makanan dan mineral, komposisi botanis, produksi biomass dan kapasitas tampung cenderung berbeda pada masing-masing topografi. Rumput yang berasal dari topografi datar lebih baik daripada rumput pada topografi miring maupun gelombang.

\section{DAFTAR PUSTAKA}

Ammar, H. S. Lopet, O. Bochi-Brum, R.Garcia and M. J. Ranila. 1991. Composition and in vitro digestibility of leaves and steams of grasses and steams of greases legumes harvested from permanent mountain meadows at different stages of maturity. Journal of Animal and Feed Sciences 8,599-600

BMKG. 2013. Data Curah Hujan Tahun 2013 STA Minangkabau. Tabing : Sumatra Barat.

Crowder, LV dan HR Chheda. 1982. Tropical Grassland Husbandry. Longman London \& New York 2: 28-29

Davis, G.K. and W. Mertz. 1987. Copper. p. 301- 364. In W. Mertz (Ed.) Trace Elements in Human and Animal Nu- 
trition. Academic Press, Inc. San Diego, CA.

Dilaga. S. H. 1992. Nutrisi Mineral Makanan Ternak (Kajian Khusus Unsur Selenium). Akademika Pressindo, Jakarta.

Fathul, F dan S. Wajihah. 2010. Competition Among These Predominant Ruminan Cellulolytic Bacteria In The Absence or Presence Of Non Cellulolytic Bacteria. Journal of Environment Mikrobiologi 147 : 21-30

Foth, F.D. Dasar-dasar Ilmu Tanah, edisi ke-7, Gadjah Mada University Press (1984).

MacPherson, A., 2000. Trace-mineral status in forages. In: D.I. Given, E. Owen, FREAxford, and HM Omed (Eds). Forage Evaluation in Ruminant Nutrition. CABI

Publishing. Walingford UK. Pp 345-371'tMannetje L, and R.M. Jones, 1992. Prosea 4: Forage. PROSEA. Bogor.

Hairiah, K., Suprayogo, D., dan Noordwijk, V. M. 200o. Reclamation of Imperata Grassland using Agroforestry. Lecture Note 5. ICRAF.

Infitria.2012. Studi Potensi Ketersediaan Hijauan di UPT Fakultas Peternakan. Fakultas Peternakan Universitas Andalas : Padang

Junaidi, M dan Diana Sawen. 2010. Botanical Varierty And Carrying Capacity Of Natural Pasture At Yapen Regency. Journal (5) : 92-97.

Marschner, H. 1995. Mineral Nutrition of Higher Plants, dalam Pengaruh Cendawan MikorizaArbuskula dan Naungan Terhadap Pertumbuhan Bibit Kayu Manis (Cinnamomum burmanii BL.), Delvian. 2006. Peronema Forestry Science Journal. 2 : 10-15.

McDonald, P., R.A. Edwards, J.F.D. Greenhalgh, and C.A. Morgan, 2002. Animal Nutrition. 6th ed. Prentice Hall. London.

McDonald, P., R.A. Edwards, J.F.D. Greenhalgh and C.A. Morgan. 1995. Animal Nutrition. Fifth Edition. Long- man Scientific and Technical Copublished in The United States with John Wiley \& Sons, Inc., New York.

McDowell, L.R. 1985. Nutrition of Grazing Ruminants in Warm Climates. Academic Press, Inc. Orlando, Florida. $756 \mathrm{pp}$.

Mcllroy, R. J. 1977. Pengantar Budidaya Rumput Tropika. Fakultas Pertanian Universitas Ibadan. Terjemahan Pradya Paramita, Jakarta.

Notohadiprawiro,T. 1991. A contribut to the identification of red-yellow podzolic soils found in the tropics. Research Journal (1) : 32-45.

Reksohadprojo soedomo. 1981. Produksi tanaman hijauan makanan ternak tropic. Fakultas ekonomi universitas gadjah mada. Djogjakarta.

Rukmana, R. 1999. Gulma dan teknik pengendaliannya. Konsius : Yogyakarta.

Sarief, E.S. 1986. Konservasi Tanah dan Air. Pustaka Buana, Bandung.

Suyitman. S. Jalaludin. Abudinar MHD. N Muis. Ifradi HR. N Jamaran. M Peto. Tanamasni. 2003. Agrostologi. Fakultas Peternakan Universitas Andalas, Padang.

Soepardi, G. 1983. Sifat dan Ciri Tanah. Institut Pertanian Bogor. Bogor. 591 halaman.

Tangdilintin, F.K. 2002. Mineral dalam Blok Multinutrien Urea-Molases. Makalah Kursus Singkat Penggunaan Teknologi Radioimmunoassay (RIA) dan Urea Multinutrisi Mollases Blok (UMMB) dalam Biologi Reproduksi Ternak. Kerjasama Fakultas Peternakan Unhas dengan Direktorat Jenderal Pendidikan Tinggi Departemen Pendidikan Nasional, Makassar.

Tillman, A.D., H. Hartadi, S. Reksohadiprodjo, S. Prawirokusumo, dan S. Lebdosoekojo. 1989. Ilmu Makanan Ternak Dasar. Gajah Mada University Press, Yogyakarta. 